\title{
Do the Well Known Prognostic Parameters in Pancreatic Ductal Adenocarcinoma Really Reflect Survival?
}

\author{
Sonay KUŞ ÖZTÜRK, Esra ERDEN
}

Department of Surgical Pathology, Ankara University, School of Medicine, ANKARA, TURKEY

\begin{abstract}
Objective: Pancreatic ductal adenocarcinoma is an aggressive tumor with short survival. In this study we aimed to investigate the effect of well-known prognostic parameters on survival in these tumors.

Material and Method: A total of 56 pancreatic ductal adenocarcinoma cases diagnosed between 2005 and 2014 were included in the study. Survival data were obtained and histopathological parameters were re-evaluated in each patient.

Results: Tumor size ( $\mathrm{p}=0.029)$, mitotic count ( $\mathrm{p}=0.030)$, lymph node metastasis $(\mathrm{p}=0.003)$, metastatic lymph node ratio $(\mathrm{p}<0.001)$ and ampullary invasion $(\mathrm{p}=0.044)$ had a statistically significant relationship with survival. However, there was no relationship between survival and tumor grade, lymphovascular and perineural invasion, and peripancreatic soft tissue invasion.

Conclusion: Our results showed that existent 2010 WHO pancreatic ductal adenocarcinoma grading parameters excluding mitotic count are subjective and not applicable. Considering that almost all of the tumors in our series were larger than $2 \mathrm{~cm}$, we think that the $2 \mathrm{~cm}$ cut-off in tumor size is insufficient to make the tumor stage pT2. Peripancreatic soft tissue invasion, which is a common finding in pancreatic ductal adenocarcinoma, should also not be assessed like adjacent tissue invasion and make the tumor reach pT3 stage independent of tumor size. It is clear that the existent WHO tumor grading and pT staging parameters need to be revised and the mitotic count, which correlates with survival, should be presented in pathology reports.
\end{abstract}

Key Words: Pancreatic ductal carcinoma, Survival, Mitosis, Grade, Peripancreatic invasion, Tumor size

This study was presented as a poster at the $26^{\text {th }}$ National Pathology Congress (2-4 November, Antalya, Turkey)

\section{INTRODUCTION}

Pancreatic ductal adenocarcinoma (PDAC), representing the majority (80-90\%) of pancreatic neoplasia, is the fourth leading cause of cancer-related deaths. Unfortunately, these tumors tend to present with non-specific symptoms and generally in advanced stages. High recurrence and metastatic capacity support the aggressiveness and high mortality rates in these tumors $(1,2)$. The most important prognostic parameter is total resection of the tumor. However, only $10-20 \%$ of the patients have surgically resectable tumors at the time of diagnosis $(3,4)$. Even in patients who undergo total resection, the overall survival only increases from 3-5 months to 10-20 months $(3,5)$.

It has been shown that tumors smaller than $3 \mathrm{~cm}$ and limited to the pancreas have a better prognosis than larger or extensive tumors (6-8). Tumor size and extension beyond the pancreas already constitute the basic parameters of the existing pT stage (1). Another basic factor for PDAC prognosis is lymph node metastasis which constitutes $\mathrm{pN}$ staging. Most of the studies about lymph node metastasis

(Turk Patoloji Derg 2018, 34:127-133)

Received : 10.01.2017 Accepted : 31.07.2017 in PDACs have reported that the metastatic lymph node ratio is more important than the presence of lymph node metastasis regarding the prognosis (9-15).

Although not taking part in $\mathrm{pT}$ or $\mathrm{pN}$ staging, it has been indicated that tumor grade, histologic subtype, mitotic count, vascular invasion, and perineural invasion also affect survival in PDACs $(5,16-21)$.

In our study, we investigated the effects of histologic and staging parameters on survival in PDACs. We aimed to show how these parameters reflect survival in these aggressive tumors.

\section{METHODS}

\section{Patient and Specimen Characteristics}

A total of 56 pancreatic ductal adenocarcinoma cases that were diagnosed between 2005 and 2014 at the Ankara University Pathology Department were evaluated. Pancreatectomy specimens were either Whipple or distal pancreatectomy materials. Ethical approval was obtained from the institute's ethics committee (Ref No. 18-766-14).

Correspondence: Sonay KUŞ ÖZTÜRK

Ankara University, School of Medicine,

Department of Surgical Pathology, ANKARA, TURKEY

E-mail: sonayku@gmail.com Phone: +90 3125958103 
Clinical data including age, gender, additional therapy and overall survival were obtained from the hospital's database system. In each case, Formalin-fixed, paraffinembedded (FFPE) tissues representing the whole tumor were sectioned into $4 \mu \mathrm{m}$ thick slices and $\mathrm{H} \& \mathrm{E}$ stained in order to re-evaluate the pathological data as tumor grade, mitotic activity, lymphovascular and perineural invasion, lymph node metastasis and resection margin status.

\section{Grading the Tumors}

All the tumors were re-evaluated according to the WHO 2010 PDAC grading criteria shown in the Table I (1).

\section{Statistics}

'SPSS for Windows 11.5' was used for data collection and statistical analysis. The Kaplan-Meier survival curve was estimated and the log-rank test was used to compare the survival. A p-value $<0.05$ was considered statistically significant.

\section{RESULTS}

\section{Patients, Operations and Follow-Up}

A total of 108 patients received a PDAC diagnosis between 2005 and 2014 at our department. Treatment and survival

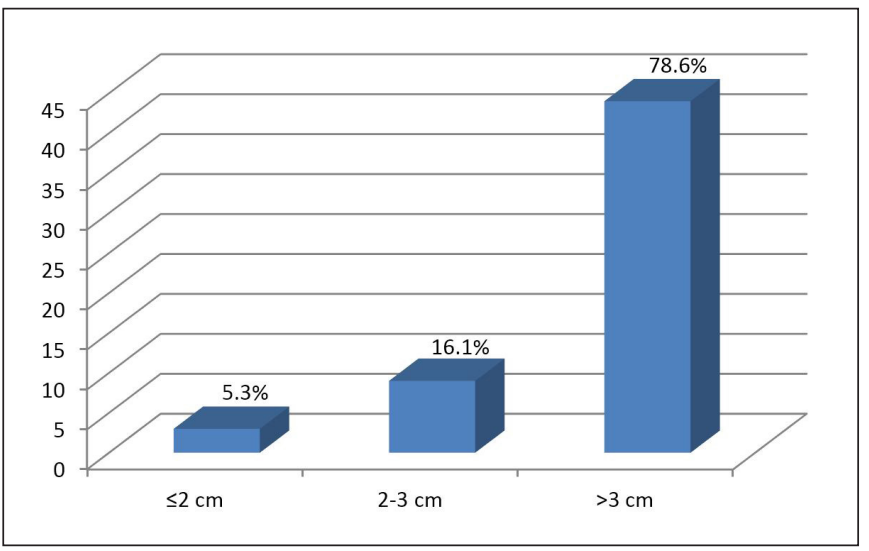

Figure 1: The distribution of the tumors according to the tumor size.

Table I: Grading criteria's in PDACs

\begin{tabular}{|c|c|c|c|c|}
\hline Tumor grade & Glandular differentiation & $\begin{array}{c}\text { Mucin } \\
\text { production }\end{array}$ & $\begin{array}{c}\text { Mitosis } \\
\text { (per 10HPF) }\end{array}$ & Nuclear features \\
\hline Grade I & Well-differentiated & Intensive & $\leq 5$ & $\begin{array}{l}\text { Little polymorphism, polar } \\
\text { arrangement }\end{array}$ \\
\hline Grade II & $\begin{array}{c}\text { Moderately differentiated duct-like structures } \\
\text { and tubular glands }\end{array}$ & Irregular & $6-10$ & Moderate polymorphism \\
\hline Grade III & $\begin{array}{l}\text { Poorly differentiated glands, abortive } \\
\text { mucoepidermoid and pleomorphic structures }\end{array}$ & Abortive & $>10$ & $\begin{array}{l}\text { Marked polymorphism and } \\
\text { increased size }\end{array}$ \\
\hline
\end{tabular}

data were obtained from 60 of them. Four patients who died due to surgical complications were excluded from the group and 56 patients were included in the study. The mean age was 63.9 years (range $44-83$ years) and the patients had a male predominance with a ratio of 1.9:1 (male, $\mathrm{n}=37$; female, $n=19)$. The majority of the patients $(66.1 \%)$ had undergone the Whipple operation and more than half of the tumors (53.5\%) were localized in the pancreatic head. The ratio of patients treated with adjuvant chemotherapy was $80.3 \%$ while $48.2 \%$ received radiotherapy. Three liver metastases and one omentum metastasis were proven by histopathological examinations. $42.9 \%$ of the patients had radiologically diagnosed metastasis and the liver constituted the majority of the suspected areas (28.5\%). During the study, 48 patients died and the mean overall survival was 15.7 months (range 1-49 months) (Table II).

The mean tumor size was $4.4 \mathrm{~cm}$ (range 2-8.5 cm) and the distribution was as follows: $78.6 \%$ had a diameter $>3 \mathrm{~cm}$, $16.1 \% 2-3 \mathrm{~cm}$ and $5.3 \% \leq 2 \mathrm{~cm}$ (Figure 1). The majority of the tumors (69.6\%) were Grade II, 28.6\% were Grade III and only $1.8 \%$ were Grade I (Figure 2- 4). The mitotic rate was $\leq 5 / \mathrm{HPF}$ ( $\mathrm{x} 400$ magnification) in $51.8 \%$ of the tumors, $6-10 / \mathrm{HPF}$ in $32.1 \%$ and $>10 / \mathrm{HPF}$ in $16.1 \%$ (Figure 5 ).

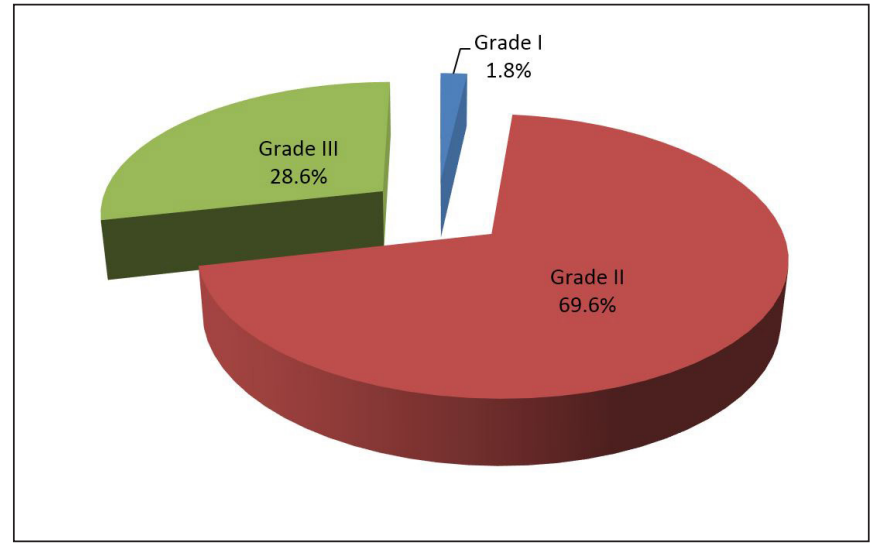

Figure 2: The distribution of tumors according to the tumor grade. 
The number of mitoses showed a more balanced distribution than the tumor grade. Among the cases, $91.1 \%$ of the tumors had perineural and $39.3 \%$ had lymphovascular invasions. The average number of dissected lymph nodes was 10.53 and $10 \%$ were metastatic.

Among the operation materials, $32 \%(n=18)$ had pancreatic resection margin, $86 \%(n=48)$ had pancreatic soft tissue and, 25\% $(n=14)$ had retroperitoneal margin positivity. Furthermore, 2\% $(n=1)$ of the Whipple operation materials

Table II: The features of the patients

\begin{tabular}{lc}
\hline Features of the patients $(\mathbf{n = 5 6})$ & Frequency $\mathbf{n}(\%)$ \\
\hline Age (year) & $63.9(44-83)$ \\
\hline Gender & $19(33.9)$ \\
Female & $37(66.1)$ \\
Male & \\
\hline Operation type & $37(66.1)$ \\
Whipple & $19(33.9)$ \\
Distal pancreatectomy & \\
\hline Tumor localization & $30(53.5)$ \\
Head & $24(42.8)$ \\
Body & $2(3.5)$ \\
Tail & \\
\hline Adjuvant chemotherapy & $45(80.3)$ \\
Present & $11(19.6)$ \\
Absent & \\
\hline Radiotherapy & $27(48.2)$ \\
Present & $29(51.7)$ \\
Absent & $24(42.9)$ \\
\hline Radiologically diagnosed metastasis & $16(28.5)$ \\
Liver & $5(8.9)$ \\
Lung & $3(5.3)$ \\
Bone & $1(1.8)$ \\
Brain & $1(1.8)$ \\
Omentum & $15.7(1-49)$ \\
\hline Overall survival (min-max) (months)
\end{tabular}

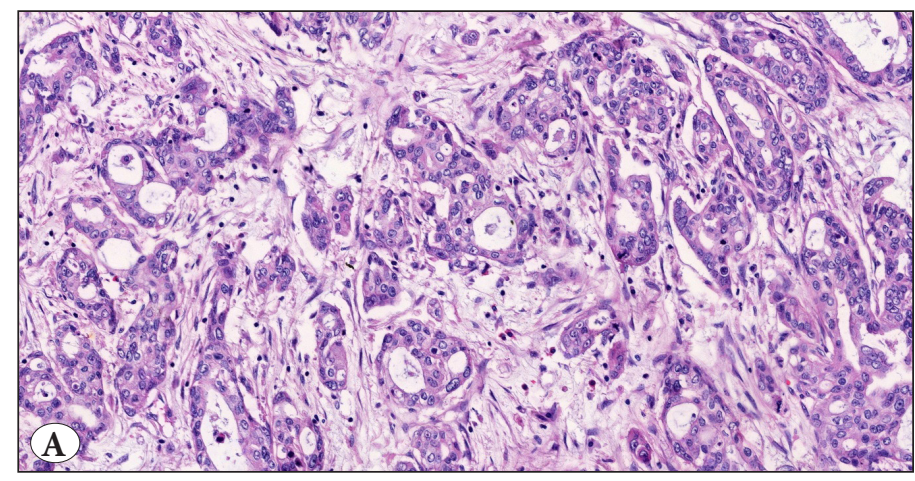

had choleduct margin positivity. The frequencies of adjacent tissue invasions were as follows: choleduct invasion $21 \%$ $(\mathrm{n}=12)$, ampullary invasion $7 \%(\mathrm{n}=4)$ and duodenum invasion $23 \%(n=13)$. The average survival of the 48 patients was 15.7 months (Figure 6).

\section{Relation Between Clinicopathological Parameters and Survival}

As shown in the Table III, tumor size $(\mathrm{p}=0.029)$, mitotic count $(\mathrm{p}=0.030)$, lymph node metastasis $(\mathrm{p}=0.003)$ and ampullary invasion $(\mathrm{p}=0.044)$ had a significant positive correlation with survival. The increase in metastatic lymph node ratio and survival had a significant negative correlation $(\mathrm{p}<0.001)$. Tumor grade was correlated neither with mitotic count $(\mathrm{p}=0.846)$ nor with survival $(\mathrm{p}=0.309)$. Therapy status, lymphovascular invasion, perineural invasion, margin positivities and adjacent tissue invasions excluding ampullary invasion had no relation with overall survival.

\section{DISCUSSION}

PDACs which have high capacity of invasion and metastasis are generally diagnosed in advanced stages. These tumors are the fourth leading cause of death among all cancers in the United States. 5 year survival rates raise from 3-5\% to $15-25 \%$ only after complete resection (1). The percentage of male patients in our group was $66.1 \%$ and the average age 63.9 years. Nearly half of the tumors (53.5\%) were localized in the pancreatic head. The average tumor size was $4.4 \mathrm{~cm}$ and the majority of them (78.5\%) were larger than $3 \mathrm{~cm}$ in diameter. Perineural invasion was a common finding (91.1\%). Average number of dissected lymph nodes was 10.5 and the metastatic rate was $10 \%$. Peripancreatic soft tissue invasion (86\%) was the most commonly observed adjacent tissue invasion in our series. Mean survival was 15.7 months. There was a remarkable fall in survival after first year. All these findings were parallel with the literature and prior studies $(1,3,5,6,11)$.

Figure 3: A,B) Grade II tumor (H\&E; x200 \& x400).

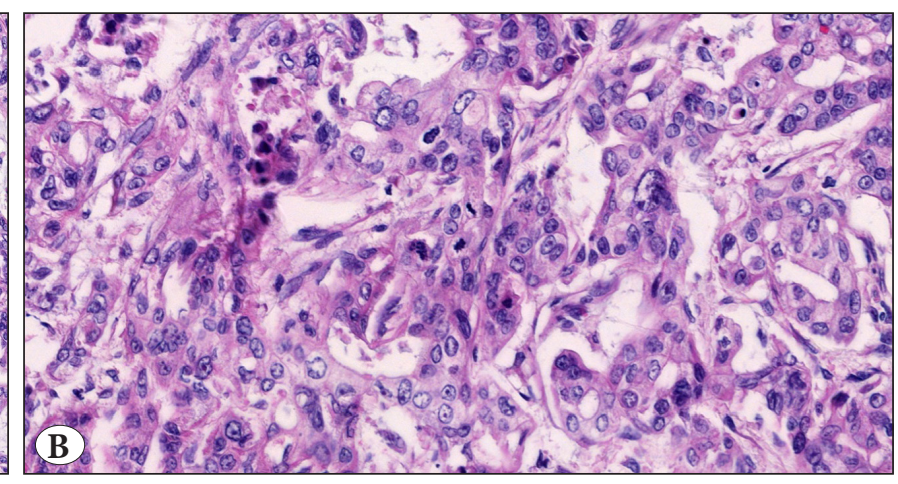


Tumor grade is one of the commonly accepted prognostic factors in PDAC. However, we could not find any statistically significant relationship between the tumor grade and survival in our series. Moreover, there was no homogeneous distribution among tumor grade groups in our series. On the other hand, a statistically significant correlation between the mitotic count and the survival was found $(\mathrm{p}=0.030)$. Except for mitotic count, WHO tumor grading parameters of PDACs such as mucin production, glandular differentiation, and nuclear features are subjective. Therefore, grading these tumors with these parameters is not applicable and causes interobserver variability. Conflicting results have been reported about the relation between tumor grade and survival in various studies. Some studies reported that tumor grade was significantly related to survival $(9,22,23)$ whereas some studies declared that existent grading parameters cause interobserver variability $(24,25)$. Therefore, tumor grading parameters in PDACs must be revised and mitotic count which has significant correlation with survival should be specified in the pathology reports (as $<5,6-10,>10$ ).

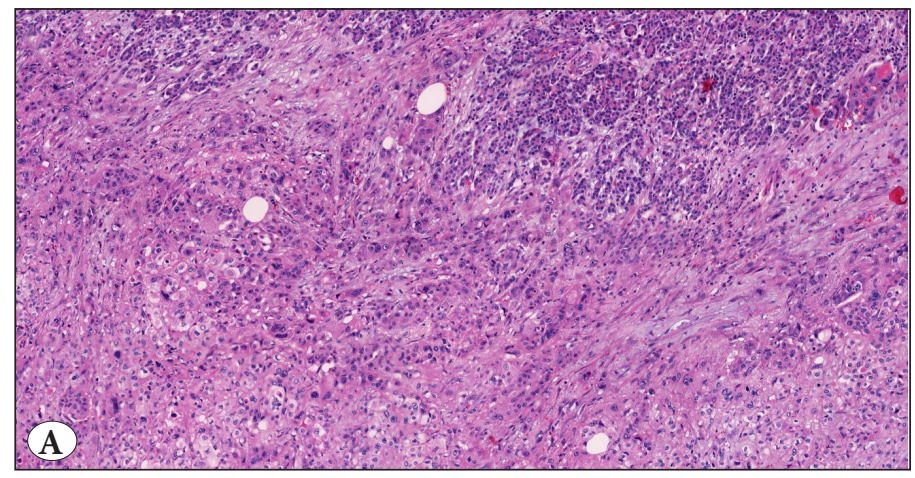

Figure 4: A,B) Grade III tumor (H\&E; x50 \& x400).

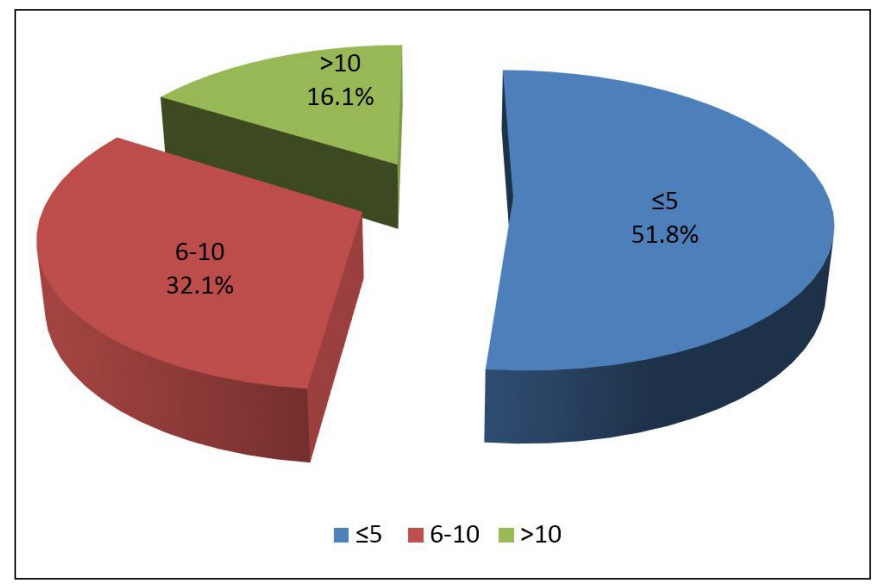

Figure 5: The distribution of tumors according to the mitotic count.
After grouping the tumors according to the tumor size ( $\leq 3$ $\mathrm{cm}$ and $>3 \mathrm{~cm}$ ), shorter survival was found in tumors $>3 \mathrm{~cm}$ $(p=0.029)$. Tumor size is already one of the parameters in existent $\mathrm{pT}$ staging. Tumors greater than $2 \mathrm{~cm}$ are assessed in pT2 stage for tumors limited to the pancreas (1). However, tumors tend to have larger sizes and $2 \mathrm{~cm}$ cut-off is not sufficient in pT staging in these tumors. Even in our series, there was no tumor smaller than $2 \mathrm{~cm}$. This problem would be solved by the recently published AJCC Cancer Staging Manual $8^{\text {th }}$ edition which recommends discriminating pT2 $(2-4 \mathrm{~cm})$ and pT3 $(>4 \mathrm{~cm})$ with the tumor size $(26)$. The effects of new cut-offs on survival would be investigated in new studies with large series.

In our series, peripancreatic soft tissue invasion had no relationship with survival. However, in the 2010 WHO TNM classification, all tumors showing peripancreatic soft tissue invasion are evaluated in the pT3 stage, independent of tumor size. The fact that the pancreas is located in fatty tissue without a capsule makes it difficult to distinguish the peripancreatic soft tissue border. Moreover, similar to

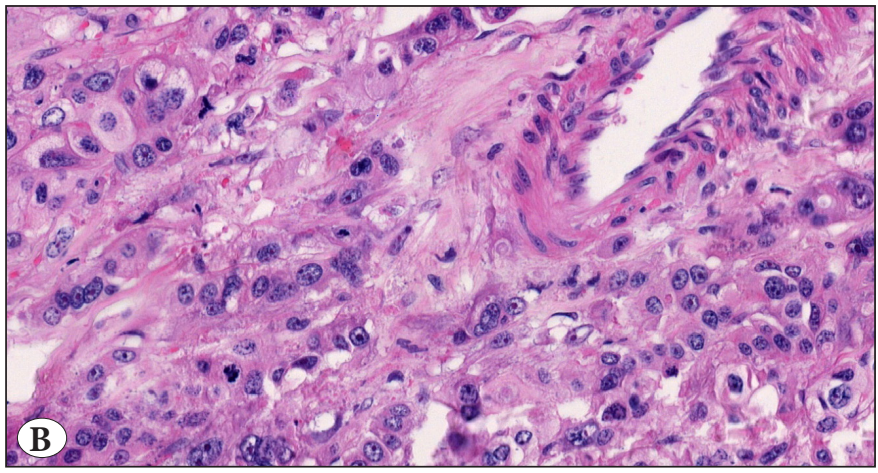

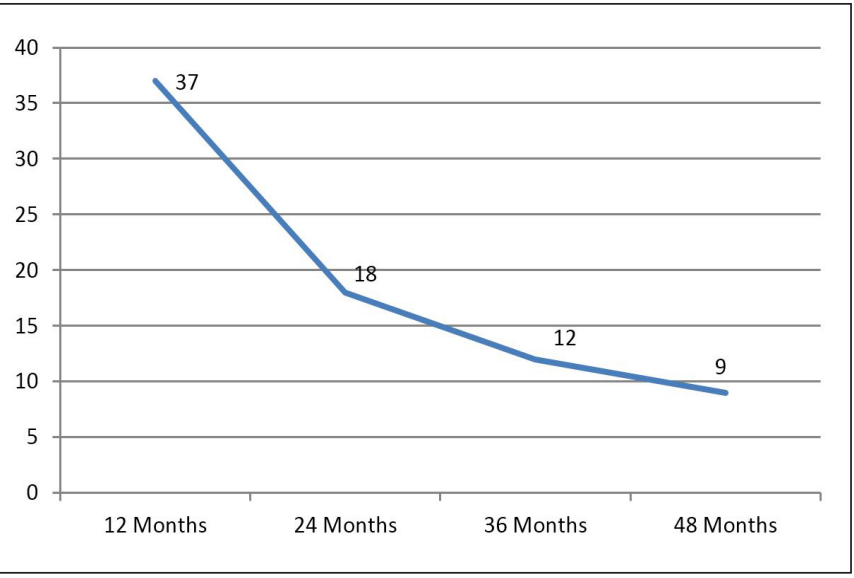

Figure 6: Overall survival-time graphics in PDAC patients. 
Table III: Relation of clinicopathological parameters and survival

\begin{tabular}{|c|c|c|c|}
\hline Feature & $\mathbf{n}$ & Median overall survival (months) & p value \\
\hline Tumor size $(\mathrm{cm})$ & & & 0.029 \\
\hline$\leq 3$ & 12 & 28 & \\
\hline$>3$ & 44 & 14 & \\
\hline Tumor grade & & & 0.309 \\
\hline Low grade (Grade I and II) & 40 & 16 & \\
\hline High grade (Grade III) & 16 & 12 & \\
\hline Mitotic count & & & 0.030 \\
\hline$\leq 5$ & 29 & 19 & \\
\hline $6-10$ & 18 & 15 & \\
\hline$>10$ & 9 & 8 & \\
\hline Lymph node metastasis & & & 0.003 \\
\hline Present & 34 & 8 & \\
\hline Absent & 22 & 28 & \\
\hline Lymphovascular invasion & & & 0.719 \\
\hline Present & 22 & 14 & \\
\hline Absent & 34 & 16 & \\
\hline Perineural invasion & & & 0.492 \\
\hline Present & 51 & 16 & \\
\hline Absent & 5 & 14 & \\
\hline Retroperitoneal margin & & & 0.164 \\
\hline Positive & 14 & 7 & \\
\hline Negative & 31 & 19 & \\
\hline Peripancreatic soft tissue & & & 0.696 \\
\hline Positive & 48 & 15 & \\
\hline Negative & 8 & 18 & \\
\hline Choledochal invasion & & & 0.605 \\
\hline Present & 12 & 19 & \\
\hline Absent & 25 & 18 & \\
\hline Duodenum invasion & & & 0.398 \\
\hline Present & 13 & 16 & \\
\hline Absent & 24 & 18 & \\
\hline Ampullary invasion & & & 0.044 \\
\hline Present & 4 & 6 & \\
\hline Absent & 33 & 18 & \\
\hline Radiologically diagnosed metastasis & & & 0.360 \\
\hline Present & 24 & 14 & \\
\hline Absent & 32 & 18 & \\
\hline Treatment & & & 0.129 \\
\hline Surgery & 11 & 5 & \\
\hline Surgery and chemotherapy & 18 & 13 & \\
\hline Surgery, chemotherapy and radiotherapy & 27 & 18 & \\
\hline
\end{tabular}


our findings, peripancreatic soft tissue invasions have been usually observed in PDACs even in the early stages (27). Also, the superiority of tumor size to peripancreatic soft tissue invasion as a prognostic factor has been shown in various studies $(28,29)$. Recently, extrapancreatic extension is no longer a part of pT3 definition in AJCC Cancer Staging Manual $8^{\text {th }}$. edition (26).

Existence of lymph node metastasis $(\mathrm{p}=0.003)$ and metastatic lymph node ratio $(\mathrm{p}<0,001)$ had a statistically significant relationship with survival in our study. Existence of lymph node metastasis, independent from metastatic lymph node number is sufficient to indicate $\mathrm{pN}$ stage $\mathrm{pN} 1$ (1). In some studies, it has been reported that metastatic lymph node ratio is more important than only the presence of lymph node metastasis on survival $(9,11,12,30,31)$. There are also important changes regarding the $\mathrm{pN}$ stage in the recently published AJCC Cancer Staging Manuel $8^{\text {th }}$ edition. In this edition, the $\mathrm{N}$ stage is subdivided into $\mathrm{N} 1(\leq 3)$ and $\mathrm{N} 2(>3)$ groups according to the number of metastatic lymph nodes (26).

In conclusion, our study showed that well known prognostic parameters like tumor grade and peripancreatic soft tissue invasion did not have any significant relationship with survival. As mitotic count showed a statistically significant correlation with survival, it should be presented in pathology reports. Most of the problematic issues (tumor size, peripancreatic soft tissue invasion and $\mathrm{pN}$ stage) we discussed in this study already underwent fundamental changes with the recently published AJCC Cancer Staging Manual $8^{\text {th }}$ edition. We look forward to hearing changes about tumor grading parameters that can make the grading of PDACs more relevant.

\section{CONFLICT of INTEREST}

The authors declare no conflict of interest.

\section{REFERENCES}

1. Bosman FT. World Health Organization Classification of Tumours of the Digestive System 4th ed. Lyon: IARC;2010: 28091.

2. Sperti C, Pasquali C, Piccoli A, Pedrazzoli S. Recurrence after resection for ductal adenocarcinoma of the pancreas. World J Surg. 1997;21:195-200.

3. Conlon KC, Klimstra DS, Brennan MF. Long-term survival after curative resection for pancreatic ductal adenocarcinoma. Clinicopathologic analysis of 5-year survivors. Ann Surg. 1996;223:273-9.

4. Sperti C, Pasquali C, Pedrazzoli S. Ductal adenocarcinoma of the body and tail of the pancreas. J Am Coll Surg. 1997;185:255-9.
5. Sohn TA, Yeo CJ, Cameron JL, Koniaris L, Kaushal S, Abrams RA, Sauter PK, Coleman J, Hruban RH, Lillemoe KD. Resected adenocarcinoma of the pancreas-616 patients: Results, outcomes, and prognostic indicators. J Gastrointest Surg. 2000;4:567-79.

6. Lim JE, Chien MW, Earle CC. Prognostic factors following curative resection for pancreatic adenocarcinoma: A populationbased, linked database analysis of 396 patients. Ann Surg. 2003;237:74-85

7. Fortner JG, Klimstra DS, Senie RT, Maclean BJ. Tumor size is the primary prognosticator for pancreatic cancer after regional pancreatectomy. Ann Surg. 1996;223:147-53.

8. Shimada K, Sakamoto Y, Sano T, Kosuge T, Hiraoka N. Reappraisal of the clinical significance of tumor size in patients with pancreatic ductal carcinoma. Pancreas. 2006;33:233-9.

9. La Torre M, Cavallini M, Ramacciato G, Cosenza G, Rossi Del Monte S, Nigri G, Ferri M, Mercantini P, Ziparo V. Role of the lymph node ratio in pancreatic ductal adenocarcinoma. Impact on patient stratification and prognosis. J Surg Oncol. 2011; 104:629-33.

10. Pawlik TM, Gleisner AL, Cameron JL, Winter JM, Assumpcao L, Lillemoe KD, Wolfgang C, Hruban RH, Schulick RD, Yeo CJ, Choti MA. Prognostic relevance of lymph node ratio following pancreaticoduodenectomy for pancreatic cancer. Surgery. 2007; $141: 610-8$.

11. Riediger H, Keck T, Wellner U, zur Hausen A, Adam U, Hopt UT, Makowiec $\mathrm{F}$. The lymph node ratio is the strongest prognostic factor after resection of pancreatic cancer. J Gastrointest Surg. 2009;13:1337-44.

12. Robinson SM, Rahman A, Haugk B, French JJ, Manas DM, Jaques BC, Charnley RM, White SA. Metastatic lymph node ratio as an important prognostic factor in pancreatic ductal adenocarcinoma. Eur J Surg Oncol. 2012;38:333-9.

13. House MG, Gönen M, Jarnagin WR, D’Angelica M, DeMatteo RP, Fong Y, Brennan MF, Allen PJ. Prognostic significance of pathologic nodal status in patients with resected pancreatic cancer. J Gastrointest Surg. 2007;11:1549-55.

14. Kang MJ, Jang JY, Chang YR, Kwon W, Jung W, Kim SW. Revisiting the concept of lymph node metastases of pancreatic head cancer: Number of metastatic lymph nodes and lymph node ratio according to N stage. Ann Surg Oncol. 2014;21:1545-51.

15. Ashfaq A, Pockaj BA, Gray RJ, Halfdanarson TR, Wasif N. Nodal counts and lymph node ratio impact survival after distal pancreatectomy for pancreatic adenocarcinoma. J Gastrointest Surg. 2014;18:1929-35

16. Sperti C, Pasquali C, Piccoli A, Pedrazzoli S. Survival after resection for ductal adenocarcinoma of the pancreas. Br J Surg. 1996;83:625-31.

17. Cleary SP, Gryfe R, Guindi M, Greig P, Smith L, Mackenzie R, Strasberg S, Hanna S, Taylor B, Langer B, Gallinger S. Prognostic factors in resected pancreatic adenocarcinoma: Analysis of actual 5-year survivors. J Am Coll Surg. 2004;198:722-31.

18. Takai S, Satoi S, Toyokawa H, Yanagimoto H, Sugimoto N, Tsuji K, Araki H, Matsui Y, Imamura A, Kwon AH, Kamiyama Y. Clinicopathologic evaluation after resection for ductal adenocarcinoma of the pancreas: A retrospective, singleinstitution experience. Pancreas. 2003;26:243-9. 
19. Nakagohri T, Kinoshita T, Konishi M, Takahashi S, Gotohda N. Nodal involvement is strongest predictor of poor survival in patients with invasive adenocarcinoma of the head of the pancreas. Hepatogastroenterology. 2006;53:447-51.

20. Brower ST, Newman RM, Pertsemlidis D, Kreel I, Aufses AH Jr. Histopathological determinants of survival in resected cases of pancreas cancer. HPB Surg. 1993;7:1-12.

21. Geer RJ, Brennan MF. Prognostic indicators for survival after resection of pancreatic adenocarcinoma. Am J Surg. 1993;165:6872 .

22. Winter JM, Cameron JL, Campbell KA, Arnold MA, Chang DC, Coleman J, Hodgin MB, Sauter PK, Hruban RH, Riall TS, Schulick RD, Choti MA, Lillemoe KD, Yeo CJ. 1423 pancreaticoduodenectomies for pancreatic cancer: A singleinstitution experience. J Gastrointest Surg. 2006;10:1199-210.

23. Rochefort MM, Ankeny JS, Kadera BE, Donald GW, Isacoff W, Wainberg ZA, Hines OJ, Donahue TR, Reber HA, Tomlinson JS. Impact of tumor grade on pancreatic cancer prognosis: Validation of a novel TNMG staging system. Ann Surg Oncol. 2013;20:43229.

24. Lüttges J, Schemm S, Vogel I, Hedderich J, Kremer B, Klöppel G. The grade of pancreatic ductal carcinoma is an independent prognostic factor and is superior to the immunohistochemical assessment of proliferation. J Pathol. 2000;191:154-61.

25. Adsay NV, Basturk O, Bonnett M, Kilinc N, Andea AA, Feng J, Che M, Aulicino MR, Levi E, Cheng JD. A proposal for a new and more practical grading scheme for pancreatic ductal adenocarcinoma. Am J Surg Pathol. 2005;29:724-33.

26. AJCC Cancer Staging Manual. Amin MB, Edge S, Greene F, Byrd DR, Brookland RK, Washington MK, Gershenwald JE, Compton CC, Hess KR, Sullivan DC, Jessup JM, Brierley JD, Gaspar LE, Schilsky RL, Balch CM, Winchester DP, Asare EA, Madera M, Gress DM, Meyer LR, editors. 8th ed. New York: Springer; 2017.
27. Ohta T, Nagakawa T, Ueno K, Kayahara M, Mori K, Kobayashi H, Takeda T, Miyazaki I. The mode of lymphatic and local spread of pancreatic carcinomas less than $4.0 \mathrm{~cm}$ in size. Int Surg. 1993;78: 208-12.

28. Park H, An S, Eo SH, Song KB, Park JH, Kim KP, Lee SS, Cho H, Seo DW, Kim SC, Yu E, Hong SM. Survival effect of tumor size and extrapancreatic extension in surgically resected pancreatic cancer: Proposal for improved T classification. Hum Pathol. 2014; 45:2341-6.

29. Saka B, Balci S, Basturk O, Bagci P, Postlewait LM, Maithel S, Knight J, El-Rayes B, Kooby D, Sarmiento J, Muraki T, Oliva I, Bandyopadhyay S, Akkas G, Goodman M, Reid MD, Krasinskas A, Everett R, Adsay V. Pancreatic Ductal Adenocarcinoma is Spread to the Peripancreatic Soft Tissue in the Majority of Resected Cases, Rendering the AJCC T-Stage Protocol (7th Edition) Inapplicable and Insignificant: A Size-Based Staging System (pT1: $</=2$, pT2: $>2-</=4$, pT3: $>4 \mathrm{~cm}$ ) is More Valid and Clinically Relevant. Ann Surg Oncol. 2016;23:2010-8.

30. Basturk O, Saka B, Balci S, Postlewait LM, Knight J, Goodman M, Kooby D, Sarmiento JM, El-Rayes B, Choi H, Bagci P, Krasinskas A, Quigley B, Reid MD, Akkas G, Maithel SK, Adsay $\mathrm{V}$. Substaging of lymph node status in resected pancreatic ductal adenocarcinoma has strong prognostic correlations: Proposal for a revised N classification for TNM staging. Ann Surg Oncol. 2015;22:1187-95.

31. Strobel O, Hinz U, Gluth A, Hank T, Hackert T, Bergmann F, Werner J, Büchler MW. Pancreatic adenocarcinoma: Number of positive nodes allows to distinguish several $\mathrm{N}$ categories. Ann Surg. 2015;261:961-9. 